\title{
Traumatic dislocation of the mandibular lateral incisor into the nasal floor
}

\author{
Gnanasekaran Arunprasad, Akilesh Ramasamy, Balasubramanian Madhan, \\ Balasubramanian Krishnan
}

Department of Dentistry, Jawaharlal Institute of Postgraduate Medical Education and Research Pondicherry, India

\section{Correspondence to} Dr Gnanasekaran Arunprasad, drgaps@gmail.com

Accepted 2 December 2015
CrossMark

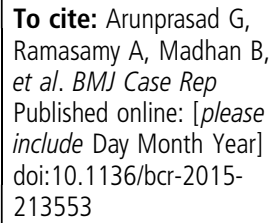

\section{DESCRIPTION}

A 23-year-old man reported for the management of panfacial fractures allegedly sustained from repeated assault with an iron rod 10 days earlier. Clinical examination revealed partially healed lacerations in the forehead, lower lip and palate, and multiple facial fractures including a palatal split.

Intraoral examination revealed luxation and grade III mobility of the maxillary central incisors and a crown fracture in the left maxillary lateral incisor. The right mandibular lateral incisor was missing, with the fracture line passing through its socket (figure 1A). Given the inability of the patient to provide reliable information and the clinical examination failing to find the tooth in adjacent tissues, it was dismissed as avulsed. To our surprise, the diagnostic CT revealed the missing tooth in the right posterior nasal floor between the hard palate and nasal mucosa (figures $1 \mathrm{~B}, \mathrm{C}$ and 2 ). Nasal endoscopy to retrieve the tooth was unsuccessful due to its submucosal location in the nasal floor. It was later retrieved through the palatal split during the internal fixation of the facial fractures

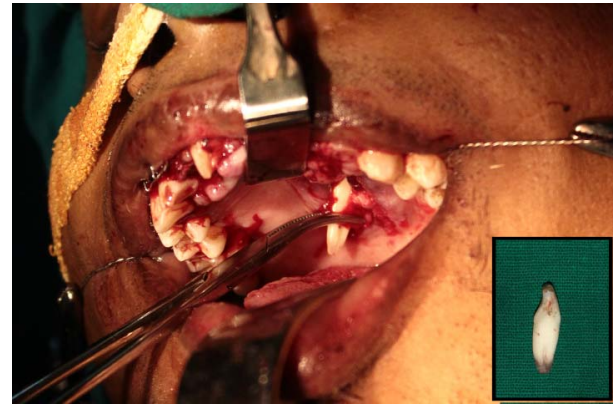

Figure 3 Intraoperative view of the tooth (shown in inset) being retrieved through the palate.

(figure 3). Considering the nature of injury and the position of dislocation, it appears that the palatal laceration and split had occurred initially allowing the tooth to dislodge through it during subsequent blow(s).

Currently available reports on traumatic displacement of teeth into the nasal cavity have been restricted to those from the maxilla. ${ }^{1-3}$ The dislocation of an intact mandibular incisor into the posterior nasal floor through the palate is very rare and
A

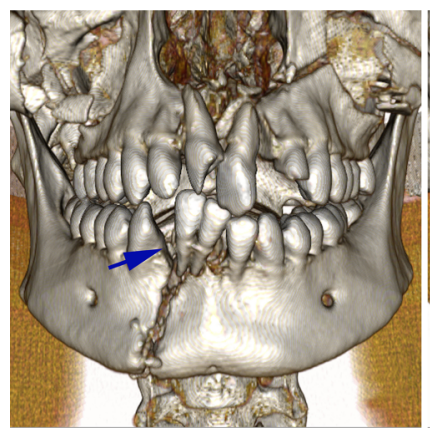

B

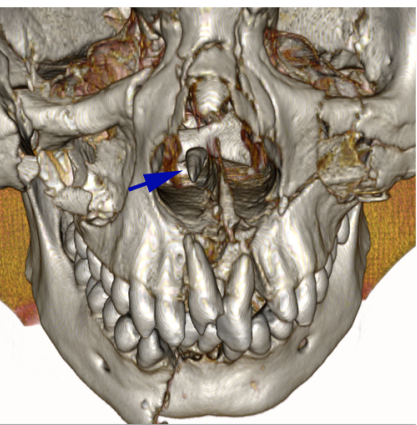

C

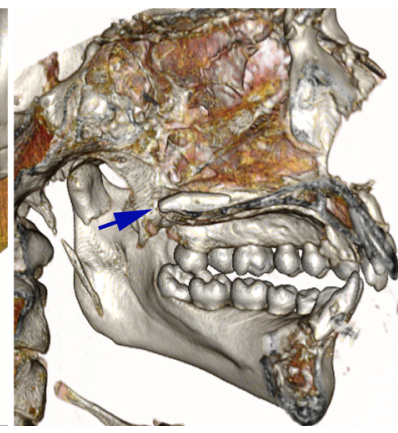

Figure 1 The three-dimensional reconstruction from CT scan showing the missing right mandibular lateral incisor (A) dislocated to the right posterior nasal floor (B and $C)$.
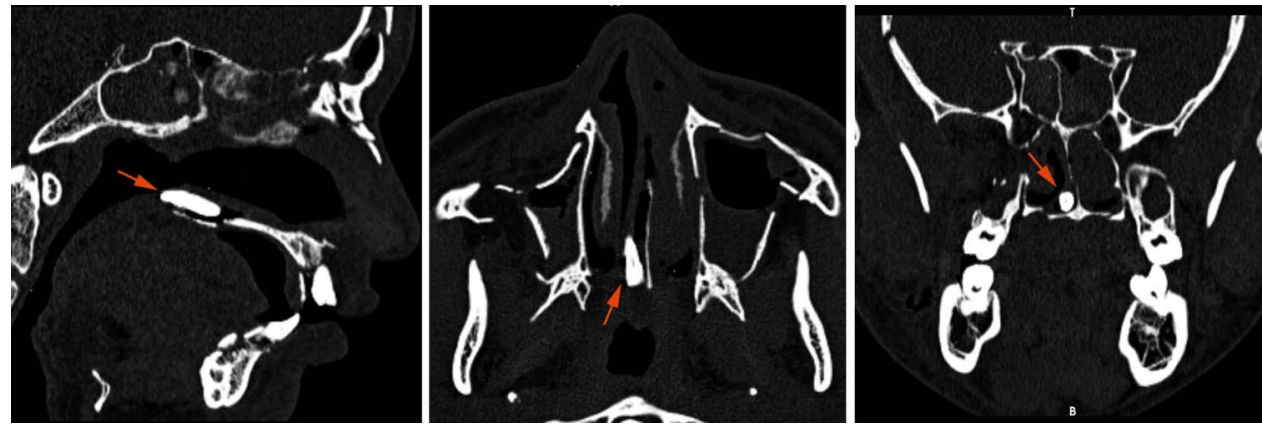

Figure 2 The two-dimensional views from CT scan showing the palatal split and the dislocated tooth between the hard palate and nasal mucosa in the right posterior nasal floor. 
has not been previously reported. Clinicians should be aware of and consider such uncommon patterns of tooth dislocation when confronted with teeth missing following maxillofacial trauma.

\section{Learning points}

- Clinicians should look beyond adjacent tissues when accounting for teeth missing after maxillofacial trauma.

- A diligent clinical and radiographic evaluation, inclusive of such unusual locations, should be undertaken before dismissing teeth as being avulsed.
Competing interests None declared.

Patient consent Obtained.

Provenance and peer review Not commissioned; externally peer reviewed.

Copyright 2015 BMJ Publishing Group. All rights reserved. For permission to reuse any of this content visit http://group.bmj.com/group/rights-licensing/permissions.

BMJ Case Report Fellows may re-use this article for personal use and teaching without any further permission.

Become a Fellow of BMJ Case Reports today and you can:

- Submit as many cases as you like

- Enjoy fast sympathetic peer review and rapid publication of accepted articles

- Access all the published articles

- Re-use any of the published material for personal use and teaching without further permission

For information on Institutional Fellowships contact consortiasales@bmjgroup.com

Visit casereports.bmj.com for more articles like this and to become a Fellow

\section{REFERENCES}

1 Martin BS. Traumatic intrusion of maxillary permanent incisors into the nasal cavity associated with a seizure disorder: report of a case. Dent Traumatol 2003; 19:286-8.

2 Gumus N, Coban YK. Traumatic displacement of teeth into maxillary sinus cavity: an unusual dentoalveolar fracture. J Craniofac Surg 2006;17:1187-9.

3 Chrcanovic BR, Bueno SC, da Silveira DT, et al. Traumatic displacement of maxillary permanent incisor into the nasal cavity. Oral Maxillofac Surg 2010;14:175-82 